\title{
The Influence of Capital Structure on Stock Returns - An Empirical Study on Industrial Companies
}

\author{
Mohammed Jamal AlZou'bi ${ }^{1}$, Ammar Daher Bashatweh ${ }^{2}$ \& Laith Faris Abu Khader ${ }^{3}$ \\ ${ }^{1}$ Faculty of Business, Accounting Dep., Al-Balqa Applied University, Salt, Jordan \\ ${ }^{2}$ Faculty of Business, Accounting Dep., Jadara University, Irbid, Jordan \\ ${ }^{3}$ Arab International Bureau Auditing, Amman, Jordan \\ Correspondence: Ammar Daher Bashatweh, Faculty of Business, Accounting Dep., Jadara University, Irbid, Jordan. \\ E-mail: a.bashatweh@jadara.edu.jo
}

Received: November 17, 2020

Accepted: December 15, 2020

Online Published: December 25, 2020

doi:10.5430/rwe.v11n6p362

URL: https://doi.org/10.5430/rwe.v11n6p362

\begin{abstract}
This study aims to examine the influence of Capital Structure on Stock Returns in Industrial Jordanian companies listed in ASE. The data collected for 60 Industrial companies in the ASE listed during $2014-2018$. The study concluded that the Long term debt to equity, Short term debt to equity, and total debt to total assets have a positive effect on stock return and the conclusions advise that industrial companies in Jordan must focus on short-term borrowing and reduce the long-term borrowing to avoid the company's inability to afford more interests.
\end{abstract}

Keywords: capital structure, stock returns, industrial Jordanian companies, short-term debt to equity, long -term debt to equity, total debt to total assets

\section{Introduction}

Capital structure is an important topic addressed by the financial and accounting literature mainly due to the lack of clarity in the construction of the capital structure in proportion to the different establishments due to the different economic environment, political, and legislative conditions of different global companies on the one hand, as well as the existence of diversity among the economic sectors on the other hand. Since the examination of such elements, which are considered the most elements affecting the capital structure, by the financial thinking of these elements, which are considered to be the most influential in the capital structure, the researchers have tended to use them clearly in the financial and accounting research that dealt with the capital structure as outlined in the studies (Faccio \& Xu, 2015) (Faulkender \& Smith, 2016), (Reunartz \& Schmid, 2016), (Leary \& Roberts,2014), (DeAngelo, Gonçalves, \& Stulz, 2017). The decision to finance the capital structure is an important decision taken by the company administration due to its impact on the return and the risks to owners, creditors, and all stakeholders, in addition to its impact on the equity returns. Many kinds of literature asserted that the leverage contributes to increased returns when the company succeeds in managing loans and achieving returns more than the interests paid, especially that the interest owed is deducted from the income tax pot; therefore, this is reflected in the rate of return (Samhan, 2015), (Githira, Nasieku, 2015).

Accounting information help companies earn finance choices, control activity, and evaluate performance, Investment in equity markets is an essential factor in the process of the economic growth and development in any country. To support this factor, the economic policies that this country implements must be encouraging and must create an investment environment that attracts investors. They must protect investors reaching for an economic construction and flourishing in such country. In general, the investors direct their money and resources to investments with lower risks and greater risk of capital recovery in a lesser time. Therefore, the return on the stock is an important component for choosing a better investment (Al-okaily, et al, 2020) (Emamgholipour, et al, 2013).

Geoff (2007) has shown that the return is the resulting wealth generated by a certain level of risk to invest capital efficiently at a certain value and for some time, and the rate of return required to achieve investment is directly proportional to the risk expected as a result of that investment, as the process of achieving equity returns is a driver of the main investment that encourages investors and motivates them to channel their money towards the highest level of wealth where equity returns are an important and key factor in making investments. Theories predict that 
companies react to the shocks of lower equity returns by reducing debt and/or repurchasing shares, and such reactions have different effects on the capital structure at least in the short term (Welch,2004).

The structure of the company's capital is a major concern for managers; theories in finance consider that debt is a financial risk factor and therefore the level of debt can change the risk, For this, the management must work to monitor risks to achieve profitability and continue to operate. The researchers studied the impact of the capital structure and the Stock Returns (Onaolapo, \& Kajola, 2010) (tahmoorespour, Mina \& Randjbaran, 2015) (Bashatweh, $\&$ Ahmed, 2020). The main contributions of this study are knowledge of the reason for the changes in Stock Returns because this leads to an increase in profits which can serve stockholders' purpose. And the study gap lies in changes in the stock prices leading to fluctuations in returns, i.e. returns are unstable in the financial market of the companies, study sample, and the following study questions can be answered:

Main question: Is there an impact for the dimensions of the capital on the Stock Returns of the Jordanian industrial companies listed in the ASE?

The researchers asked these sub-questions:

Sub-question 1: Is there an impact for the short-term debt ratio to equity on the Stock Returns of the Jordanian industrial companies listed in the ASE?

Sub-question 2: Is there an impact for the long-term debt ratio to equity on the Stock Returns of the Jordanian industrial companies listed in the ASE?

Sub-question 3: Is there an impact for the total debt to the total assets on the Stock Returns of the Jordanian industrial companies listed in the ASE?

\subsection{Study Objectives and Important}

The study aimed to understand the impact of the capital structure on the Stock Returns in the industrial companies listed in the ASE during the period 2014-2018. The study is important since it tries to provide an integrated theoretical framework on the variables of the study represented by the capital structure and the Stock Returns and discuss the relationship among these variables so that the researchers hope that this will provide an important reference for researchers and academics in the future and contribute to enriching the theoretical frameworks available. The study also makes recommendations to decision-makers in all the Jordanian industrial companies to support their future decisions.

\section{The Theoretical Part and Literature Review}

\subsection{Capital Structure}

It is a term for the method adopted by the company to finance its assets through several elements such as equity and indebtedness. It is described by calculating the ratio of equity and indebtedness to capital. The capital structure is an important element used to measure the value of the company (Vătavu, 2015). Furthermore, (Frank \& Goyal, 2009) examined potential factors affecting the composition of the capital structure, as follows: 1. The average debt for industry 2. The difference between the B.V and M.V 3. asset size. 4 company's growth and profit are 5. Company size 6. Expected inflation.

For example, (Harris, 2015) showed that financial flexibility is one of the high levels positively associated with fixed debt levels, and with companies increasing their specific payment policies. Such companies are more compliant to allow more limited flexibility in their capital structure. (Pindado,Requejo,\& Rivera, 2017) also explained that the debt levels become lower with weak expected performance in the wider economy given the fear of the administrations from the consequences of making decisions concerning borrowing risk, liquidation costs, and bankruptcy when resorting to borrowing financing. (Bates, Kahlem,\& Stulz. 2009) showed evidence for the fact that the increased cash flow risks had led to the expansion of the corporate cash holdings to meet these increased risks, which represented an incentive for companies to retain additional cash. This in turn leads to insufficient cash flows for companies for operating needs.

\subsection{Stock Returns}

The return is defined as the real cash flow achieved by the investor as a result of investing his money in a period and carrying out a particular project. The return is measured for the acquisition period by subtracting the purchase price from the selling price and adding cash distributions to it divided by the purchase price (Haddad, 2009). Moreover, (Geoff, 2007) defined the return as the resulting wealth generated by a certain level of risk to invest capital efficiently at a certain value for some time, and the rate of return to be achieved on investment is directly 
proportional to the risk expected as a result of that investment. Investors need data and information from published financial reports from companies to freely choose and trade between high and low-risk returns. (Anwaar, 2016) argues that investors can depend on financial statements as an important element to help them determine the best opportunities to put their money and resources in a particular company. Furthermore, the most important key indicators for making investment decisions in the stock market is the equity return which is also used by most potential investors and the current investors in future forecasts and financial analysis (Mashayekhi, Fadaee, \& Rahmani, 2008).

\subsection{Theories and Linking Among Capital Structure and Stock Return}

Some theories predict that Firms react to the shocks of lower Stock Returns through the reduction of debt and/or repurchasing shares, which are considered reactions that have different effects on the capital structure at least in the short term (Welch, 2004). Given the positive impact of the maximum value of the company for the shareholders, the latter will focus on providing the incentives to the management being agents who manage their funds and investments. The goal is increasing the management's effectiveness and efficiency in maintaining the optimal capital structure, which often is translated to an optimal and targeted capital structure. Also, the risks of the acquisition resulted from a capital structure defect might prompt the management to adjust the best and optimal capital structure (Leary \& Roberts, 2005). (Graham \& Harvey, 2001) shows that there is medium support for the directors who follow the targeted capital structure and its optimal structure from the perspective of the barter theory because of the financial leverage in the market increases during the decline of the share price and paying the debts. Such theory is evident in the previous literature where the managements, in times of the decline of the long share price, choose activities to lower the financial leverage such as issuing shares or issuing debt bonds. Furthermore, it is expected that managers will decrease the leverage by reducing debt through issuing shares especially that issuing shares might result in further depreciation of the share price. Many studies are conducted for the capital structure particularly about barter theory, agency theory, as well as the theory of the sequencing of sources of financing. The literature indicated that the barter theory argues in the appearance of the optimal capital structure that balances the interests of the debt tax against the bankruptcy costs for debt (Frank \& Goyal, 2009). At a similar level, the Agency's theory defends the existence of an optimal capital structure that reduces the agency's total costs (Jensen, 1986).

\subsection{Previous Studies}

Nasih and al-Badran, (2014): This study examination of the financing structure and profitability of Iraq industrial companies listed in ISE during 2011-2014. The main objective of these articles is to investigate the impact of financing structure and ROA. The results showed that there was no relationship between ROA and financing structure.

Samhan, (2015): This study investigates the capital structure, leverage, and profitability on the value of Jordanian education and investment companies. The main objective of these articles is to determine if the impact of capital structure, leverage, and profitability on the value. The results showed that a statistical impact for the financial leverage and the capital structure on the value of the education and investment companies in Jordan and no statistical impact for the level of the return achieved by the shareholders as a result of investing their money in the Jordanian education and investment companies on the market value of these companies.

Ajanthan, (2013). This study investigates corporate governance, capital structure, and profitability. The main objective of these articles is to determine if the impact of corporate governance on capital structure, and profitability. The results showed that there is no statistical significance between corporate governance practices among regards to the capital structure and profitability.

Budiman, (2015). This study investigates corporate governance, the value of the company, and its shareholders with the capital structure as a mediate variable. It showed no statistical impact on the formation of the management board, institutional ownership, and profitability on the shareholder value. The capital structure doesn't mediate the relationship among Tobin q, and size of the board.

Shan and Gong, (2017). This study investigates the capital structure, performance. The main objective of these articles is to determine if the impact of capital structure on the performance of Chinese companies. The results showed that the concentration of ownership an important in companies, and the concentration of ownership will reduce performance. 


\section{Research Design}

\subsection{Population and Sample of Study}

This research population composed of all the 66 Jordanian industrial companies listed in the ASE, while the study sample after referring to the Sekran equation, consisted of (60) companies of the study population and excluded 6 companies because their financial reports were not published during the study period. The study was carried out for the period 2014 to 2018 where companies included in the sample continue providing their annual data.

\subsection{Data Collection}

The researchers relied on the preliminary sources represented in the published annual reports of the Jordanian industrial companies for the period 2014-2018. The secondary sources included the Arab and foreign sources of previous studies, scientific research, publications and books, which were obtained from public libraries, Jordanian university libraries, databases, and search engines available to the researcher on the Internet

\subsection{Hypothesis of the Study}

HO1: There is no effect for Capital Structure on Stock Returns.

HO1.1: There is no effect for total debt to total assets on Stock Returns.

HO1.2: There is no effect for Long -term debt to equity on Stock Returns.

HO1.3: There is no effect for total debt to total assets on Stock Returns

\subsection{Regression Model}

$$
\text { S.Rit }=\mathrm{a} 0+\mathrm{a} 1 \text { SDit+ a2 LDit }+\mathrm{a} 3 \text { TDit }+ \text { eit }
$$

\section{Where:}

S.R $=$ Stock Returns

$\mathrm{SD}=$ short-term debt to equity

$\mathrm{LD}=$ Long-term debt to equity

$\mathrm{TD}=$ Total debt to Total assets

$\mathrm{a}=$ constant

$\mathrm{e}=$ random error

a1-a3= the coefficients of variables

\subsection{Multicollinearty}

To ensure that there is no significant relationship between the dimensions, considering that the self-correlation among the dimensions will distort the results by amplifying the selection factor, it was important to solve the correlation problem among these dimensions before starting the statistical analysis. The results in the table showed that the VIF for all the dimensions was less than 5, indicating that there is no problem of interference among the dimensions of the independent variable. The VIF value for the dimensions of the capital structure ranged from (1.102 to 2.499). Also, it was clear that the tolerance allowed for all the variables was greater than (0.05), which reinforces the judgment that there is no problem of multiple linear correlations among these dimensions.

Table 1. Multicollinearty test

\begin{tabular}{lcc}
\hline Variables & VIF & Tolerance \\
\hline Short-term debt to equity & 2.386 & 0.419 \\
\hline Long-term debt to equity & 2.499 & 0.400 \\
\hline Total debt to Total assets & 1.102 & 0.907 \\
\hline
\end{tabular}




\subsection{Unit Root Test}

Table 2. Unit root test

\begin{tabular}{lll}
\hline Variables & T value & Sig \\
\hline Short-term debt to equity & -15.322 & 0.000 \\
\hline Long -term debt to equity & -11.103 & 0.000 \\
\hline Total debt to total assets & -24.309 & 0.000 \\
\hline Stock Returns & -19.104 & 0.000 \\
\hline
\end{tabular}

The table shows the unit-roots test results. The unit root test is one of the standard tools for time series econometricians, (Atil \& Fellag, 2010). This study uses Levin, Lin \& Chu Test: Table regards the results of a stability test of data. All the data of the time series used in the study are stable over time because all the p-values of the variables exceed $5 \%$.

\subsection{Model Estimation}

The nature of the study data goes to many years for many companies and they form the (Panel Data) which requires an estimation to the model appropriate for testing such data since it contains time series and cross-sectional data by comparing the results of three models.

1. Pooled regression Model (PRM)

2. Fixed effect Model (FEM)

3. Random effect Model (REM)

And this Study uses Hausman Test For the choice between models:

Table 3. Hausman Test

\begin{tabular}{lccc}
\hline Model & $\mathrm{Ch}^{2}$ & Prob. & Appropriate Model \\
\hline H01 & 8.400 & 0.0383 & Fixed \\
\hline H01.1 & 6.177 & 0.0129 & Fixed \\
\hline H01.2 & 2.557 & 0.1097 & Random \\
\hline H01.3 & 13.332 & 0.0003 & Fixed \\
\hline
\end{tabular}




\section{Hypothesis Testing}

Table 4. The summary of results to investigate the First hypothesis

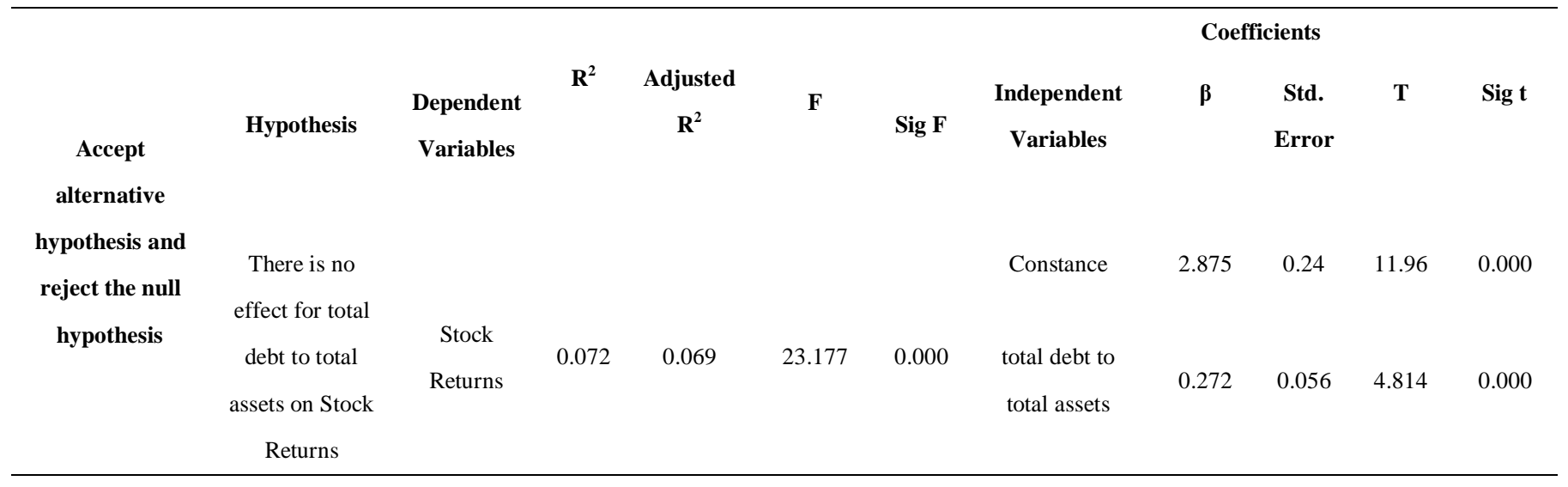

Table 4 shows the analysis of the impact of the independent variable short-term debt to equity on the Stock Returns variable. The Results shows a significant of the model at the (0.000) level with an F value of (176.380) and with an adjusted $\mathrm{R}^{2}$ of $(36.4 \%)$ also the Table shows the analysis for the variable, where short-term debt to equity has a positive significant association with Stock Returns at $5 \%$ level.

Table 5. The summary of results to investigate the second hypothesis

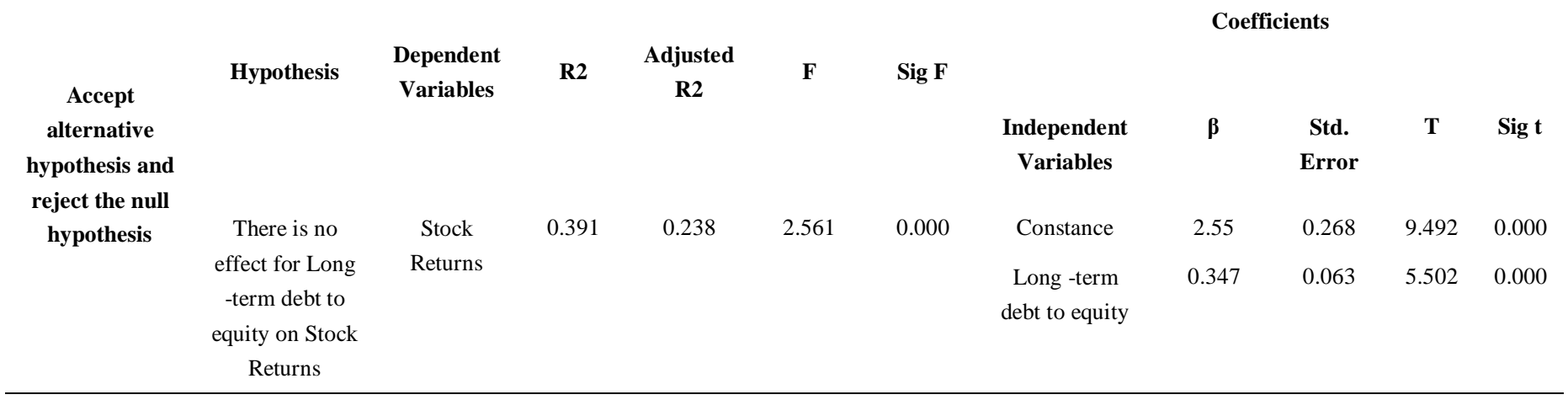

Table 5 shows the analysis of the impact of the independent variable long-term debt to equity on the Stock Returns variable. The Results shows a significant of the model at the (0.000) level with an F value of (2.561) and with an adjusted R2 of $(39.1 \%)$ also the Table shows the analysis for the variable, where long-term debt to equity has a positive significant association with Stock Returns at 5\% level. 
Table 6. The summary of results to investigate the third hypothesis

\begin{tabular}{|c|c|c|c|c|c|c|c|c|c|c|c|}
\hline \multirow{4}{*}{$\begin{array}{c}\text { Accept } \\
\text { alternative } \\
\text { hypothesis and } \\
\text { reject the null } \\
\text { hypothesis }\end{array}$} & \multirow{2}{*}{ Hypothesis } & \multirow{2}{*}{$\begin{array}{c}\text { Dependent } \\
\text { Variables }\end{array}$} & \multirow{2}{*}{$\mathbf{R}^{2}$} & \multirow{2}{*}{$\begin{array}{c}\text { Adjusted } \\
\qquad \mathbf{R}^{2}\end{array}$} & \multirow{2}{*}{$\mathbf{F}$} & \multirow{2}{*}{$\begin{array}{c}\text { Sig } \\
\text { F }\end{array}$} & \multicolumn{5}{|c|}{ Coefficients } \\
\hline & & & & & & & $\begin{array}{c}\text { Independent } \\
\text { Variables }\end{array}$ & B & $\begin{array}{l}\text { Std. } \\
\text { Error }\end{array}$ & $\mathbf{T}$ & Sig $\mathbf{t}$ \\
\hline & There is no & Stock & 0.072 & 0.069 & 23.177 & 0.000 & Constance & 2.875 & 0.24 & 11.96 & 0.000 \\
\hline & $\begin{array}{l}\text { effect for total } \\
\text { debt to total } \\
\text { assets on Stock } \\
\text { Returns }\end{array}$ & Returns & & & & & $\begin{array}{l}\text { total debt to } \\
\text { total assets }\end{array}$ & 0.272 & 0.056 & 4.814 & 0.000 \\
\hline
\end{tabular}

Table 6 shows the analysis of the impact of the independent variable total debt to total assets on the Stock Returns variable. The results show a significance of the model at the (0.000) level with an F value of (23.177) and with an adjusted $\mathrm{R}^{2}$ of $(6.90 \%)$ also the Table shows the analysis for the variable, where total debt to total assets has a positive significant association with Stock Returns at $5 \%$ level.

Table 7. The summary of results to investigate the main hypothesis

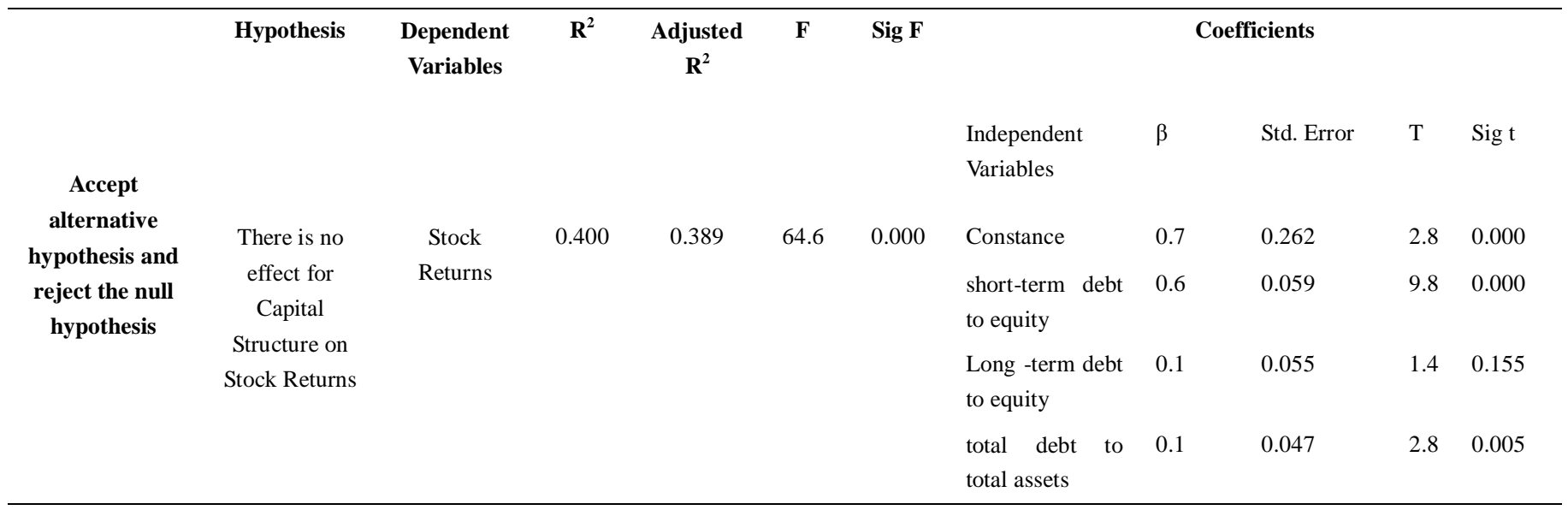

Table 7shows the analysis of the impact of the independent variable capital structure on the Stock Returns variable. The results show a significance of the model at the (0.000) level with an F value of (64.620) and with an adjusted R2 of $(38.90 \%)$ also the Table shows the analysis for all of the variables, where short-term debt to equity has a positively significant relationship with Stock Returns at 5\% level. Also, there is no significant relationship between Long -term debt to equity and Stock Returns at the 5\% level. In addition, total debt to total assets has a positively significant with Stock Returns at 5\% level.

\section{Conclusion}

The study investigates the influence of Capital Structure on Stock Returns in Industrial companies in Jordan listed in ASE during 2011 - 2018. To date, empirical evidence on the relationship linking Capital Structure on Stock Returns is limited. The research provides the current literature, knowledge of the reason for the changes in Stock Returns Because this leads to an increase in profits which can serve stockholders' purpose, and examining the effect of Capital Structure on Stock Returns in Industrial by using data from Jordanian Companies By testing the hypotheses of the study, the results verified the research hypotheses regarding is a significant effect of capital Structure on Stock Returns in Industrial Jordanian Companies. And findings the impact of the capital structure on Stock Returns might be attributed to the efficiency of the management of the public industrial companies, so that a decrease in the long-term borrowing has been observed in order to avoid the company's inability to bear significant interests, especially in the circumstances of high-interest rates, and thus focusing on the short-term borrowing. This indicates 
an impact on the political and economic instability in the region, thus creating a blurring of the future vision of the economy and thus relying on self-financing and not expanding the financial leverage, especially the long-term borrowing. The result of this study is inconsistent with (Nasih and Badran, 2014), which indicated that there was no relationship between the ratio of indebtedness and the profitability while it was consistent with (Githira and Nasieku, 2015) which concluded a strong positive relationship between the capital structure and the structure of the assets in addition to (Hong and Gong, 2017) which indicated that the ownership structure affects the performance of companies.

\section{References}

Alagathurai, A. (2013). Impact of corporate governance practices on firm capital structure and profitability: A study of selected hotels and restaurant companies in Sri Lanka. Research Journal of Finance and Accounting, 4(10).

Al-Okaily, A., Abd Rahman, M. S., Al-Okaily, M., Ismail, W. N. S. W., \& Ali, A. (2020). Measuring Success of Accounting Information System: Applying the DeLone and McLean Model at the Organizational Level. Journal of Theoretical and Applied Information Technology, 98(4).

Anwaar, M. (2016). Impact of firms performance on stock returns (evidence from listed companies of ftse-100 index London, UK). Global Journal of Management and Business Research.

Atil, L., \& Fellag, H.(2010). On the stability of the unit root test. Journal Afrika Statistika, 5(1), 228-237. https://doi.org/10.4314/afst.v5i1.71039

Bashatweh, A. D., \& Ahmed, E. Y. (2020). Financial Performance Evaluation of the commercial banks in Jordan: Based on the CAMELS Framework. International Journal of Advanced Science and Technology, 29(5), 985-994.

Bates, T. W., Kahle, K. M., \& Stulz, R. M. (2009). Why do US firms hold so much more cash than they used to?. The Journal of Finance, 64(5), 1985-2021. https://doi.org/10.1111/j.1540-6261.2009.01492.x

Budiman, J. (2015). Corporate governance, capital structure and shareholder value of Indonesian stock exchange firms. Jurnal Manajemen Maranatha, 15(1).

DeAngelo, H., Gonçalves, A. S., \& Stulz, R. M. (2018). Corporate deleveraging and financial flexibility. The Review of Financial Studies, 31(8), 3122-3174. https://doi.org/10.1093/rfs/hhx147

Emamgholipour, M., Pouraghajan, A., Tabari, N. A. Y., Haghparast, M., \& Shirsavar, A. A. A. (2013). The effects of performance evaluation market ratios on the stock return: Evidence from the Tehran stock exchange. International Research Journal of Applied and Basic Sciences, 4(3), 696-703.

Faccio, M., \& Xu, J. (2015). Taxes and capital structure. Journal of Financial and Quantitative Analysis, 50(3), 277-300. https://doi.org/10.1017/S0022109015000174

Faulkender, M., \& Smith, J. M. (2016). Taxes and leverage at multinational corporations. Journal of Financial Economics, 122(1), 1-20.

Frank, M. Z., \& Goyal, V. K. (2009). Capital structure decisions: which factors are reliably important?. Financial management, 38(1), 1-37. https://doi.org/10.1111/j.1755-053X.2009.01026.x

Geoff, C. D. (2007). Getting the most return for risk, part2. copyright Quantxt, inc page.

Githira, W. C., \& Nasieku, T. (2015). Capital structure determinants among companies quoted in securities exchange in East Africa. International Journal of Education and Research, 3(5), 483-496.

Graham, J. R., \& Harvey, C. R. (2001). The theory and practice of corporate finance: Evidence from the field. Journal of Financial Economics, 60(2-3), 187-243. https://doi.org/10.1016/S0304-405X(01)00044-7

Haddad, Fayez (2009). Financial Management. Dar Alelm. Amman Jordan.

Harris, C. (2015). Financial flexibility and capital structure. Acad. Account. Financ. Stud. J. 19(2), 119-127.

Jensen, M. C. (1986). Agency costs of free cash flow, corporate finance, and takeovers. The American Economic Review, 76(2), 323-329. Retrieved from https://www.jstor.org/stable/1818789

Leary, M. T., \& Roberts, M. R. (2005). Do firms rebalance their capital structures?. The Journal of Finance, 60(6), 2575-2619. https://doi.org/10.1111/j.1540-6261.2005.00811.x

Leary, M. T., \& Roberts, M. R. (2014). Do peer firms affect corporate financial policy?. The Journal of Finance, 69(1), 139-178. https://doi.org/10.1111/jofi.12094 
Mashayekhi, B., Fadaeem, N. M., \& Rahmani, K. R. (2009). Explanatory power of accruals (abnormal) stock returns in relation to behavior: Effects of corporate profits and the systematic risk. Journal of Accounting and Auditing, 4, 1-2.

Nasih, \& al-Badran. (2014). The relationship of the financing structure to the profitability of the company An applied study on a sample of industrial sector companies registered in the Iraq Stock Exchange for the period (2004-2011). Journal of Economic Sciences, 10(37).

Onaolapo, A. A., \& Kajola, S. O. (2010). Capital structure and firm performance: Evidence from Nigeria. European Journal of Economics, Finance and Administrative Sciences, 25(1), 70-82.

Pindado, J., Requejo, I., \& Rivera, J. C. (2017). Economic forecast and corporate leverage choices: The role of the institutional environment. International Review of Economics \& Finance, 51, 121-144. https://doi.org/10.1016/j.iref.2017.05.006

Reinartz, S. J., \& Schmid, T. (2016). Production flexibility, product markets, and capital structure decisions. The Review of Financial Studies, 29(6), 1501-1548.

Samhan, H. M. (2015). The effect of capital structure, financial leverage and profitability on the value of the Jordanian education and investment companies. Recherches économiques et managériales, 7.

Shan, H., \& Gong, G. (2017). The impact of ownership structure on firm performance: static and dynamic panel data evidence from china's listed companies. In 2016 National Convention on Sports Science of China (p. 01017). EDP Sciences. https://doi.org/10.1051/ncssc/201701017

Tahmoorespour, R., Mina, A., \& Randjbaran, E. (2015). The impact of capital structure on stock returns: International evidence. Hyperion Economic Journal, 1(3), 56-78.

Vătavu, S. (2015). The impact of capital structure on financial performance in Romanian listed companies. Procedia Economics and Finance, 32, 1314-1322. https://doi.org/10.1016/S2212-5671(15)01508-7

Welch, I. (2004). Capital structure and stock returns. Journal of Political Economy, 112(1), 106-131. Retrieved from https://www.jstor.org/stable/10.1086/379933

\section{Copyrights}

Copyright for this article is retained by the author(s), with first publication rights granted to the journal.

This is an open-access article distributed under the terms and conditions of the Creative Commons Attribution license (http://creativecommons.org/licenses/by/4.0/). 